\title{
A School That Forms? \\ A Look at the Years of the Communist Regime and the Present
}

\author{
FRANTIŠEK NEUPAUER
}

Nation's Memory Institute in Bratislava

frantisek.neupauer@gmail.com

\begin{abstract}
Based on personal experience of students and use of archives, the study shows how totalitarian ideology of communist regime influenced students and aimed at socialization of villages - collectivization. Real examples imply various questions in relation to the past and the future: How should teachers influence students nowadays? Should history classes focus on historical facts, or should they form students and their values?
\end{abstract}

KEY WORDS: historical empathy, communist regime, collectivization, school

Schools bring together two different strange people: a student and a teacher. Teacher, (often) as a civil servant, aims to provide education, knowledge, but may also try to form the pupil, to guide him on a way to his future profession. How did teachers shape students during the communist regime? Memories from Communist regime era are still mystery when it comes to relationship of a teacher and a student. Should teachers just present the facts, or should they bring values into education?

\section{The Past}

During the communist regime in Slovakia, it was not easy to become a teacher without sacrificing one's own integrity. Firstly, the regime guarded the sphere of education from 
any "anti-communist elements" - from people burdened by democratic thoughts, or religious ideology. Therefore often intervention in changing young people's life mission stemmed directly from the family environment. Knowing that the totalitarian regime wanted the teachers to be an extended arm of propaganda, a parent said these harsh words to his daughter: "I would rather see you dead than study to become a teacher."

Memoires of a scientist, a university professor Paul Winzer (Memories of 2002), contain specific requirements of the new regime for teachers and pupils at the Gymnázium ${ }^{2}$ in Kežmarok. Wizner presents a dilemma with which teachers at that time had to deal."When we take an ahistorical look at beautifully and internally diversified Slovak literature in the interwar period and we apply the criteria of socialistic realism that were required at the beginning of the 50's, what remains from this immense riches are works of Peter Jilemnický a Fraňo Král and as a work of realism and non-communist progressive traditions and social criticism of Jesensky, "Democrats". Books by the so called "inappropriate" authors were discarded from public and school libraries, from the curriculum, and the aim was to delete these authors from a memory of a nation. Against Novomesky and other members of pre-war communist group surrounded around newspaper $D A V$, a pamphlet publication was published for the purposes of education. " ${ }^{3} A$ teacher of Slovak language should not have stepped out of the framework required by the state. "She should not know the surnames of the authors that we could not even say out loud. The framework did not allow that, and exceeding might have had severe consequences for her and anybody else. Prominent names, such as Beniak, Hronský, Urban a common student never heard, unless he had educated parents. "4

These memories show vigor of the teacher's approach towards a student. The aim of the totalitarian regime (lat. totus - all) was to create a unified society without memory.

1 Author's archive (AA) - interview with Peter Dubovský (1921, Rakovice - 2008, Ivánka pri Dunaji) on May 14, 2005.

2 The Slovak educational system differentiated between several types of high schools. High schools focused on practical skills in industry and production were called the apprentice high schools, where the teachers finished with an apprentice license. Another type were vocational high schools, again strongly oriented on practical skills for industry and services. The last type of high schools was called "Gymnázium" and it was regarded as a prominent high schol providing general education in both social and natural sciences. Students of such high schools usually aimed for university education.

3 WINCZER, P.: Gymnázium v Kežmarku [High school of Kežmarok] in 1950 - 1953 viewed from personal retrospective. In. GOCELIAKOVÁ, M. (comp.): 75 years of High school in Kežmarok: Alter ego, 2003.

$4 \quad$ Ref. 2

DOI: 10.1515/eas-2015-0012 C University of SS. Cyril and Methodius in Trnava. All rights reserved. 
Those who openly resisted got into the clash with the regime. Therefore a specific model developed, a model of existence which carried features of schizophrenic opinions, thoughts and behavior. The main principle was separation between the official public sphere, the school, from the private or semi-private spheres, such as family. In its application this meant that what was said at home could (or should) not be said outside, for examplein school. Students often did things at home which they were not supposed to talk about at school (e.g. "we listened to Voice of America, Radio Free Europe, Radio Vatican, read Orwell's book 1984 and so on.") Examples of such a dual viewconcerned mainly public and political topics, and subjects that were directly connected with the ideology. The ideologically most sensitive subjects were naturally social studies (e.g. history, literature), on the other hand the ideological influence was lower in natural sciences (here the most ideologically influenced was Biology), but exact sciences resisted the ideology the best." Although the author of memoirs excludes natural sciences from the ideologist package, our research has proven that even math classes aimed to form students ideologically. Textbooks and exercises were created in line with the official rhetoric and ideology: "Exercise: Count how much it is: Eight American tanks minus three Soviet tanks." Even assignments had to include signs of strong role of USSR.

A subject at the edge was Biology. During the classes of Biology at Gymnázium Kežmarok not enough attention was paid to "the Soviet sciolist Olga Lepesinska, who supposedly successfully merged the boundary between lifeless and live, but her theory became a subject of propaganda for students of Citizenship." 6 This way they were introduced to materialistic approach over the idealistic.

Classes of Religion, which were part of school curriculum before, were stopped in 1948/1949. Besides banning the subject, "a school inquisition" was founded to observe who practiced religion: ...during my studies at gymnázium, classmates who were believers were bullied - in some special cases school's department for Youth Union and its chairman recommended not to accept them to university due to "religion bias.",

Experiences of political prisoners and their children often touch upon the topic of "school suffering." Having a parent imprisoned was not only a personal topic of "childhood without a father or a mother", but it also brought mockery from classmates and even teachers. Teachers, especially those "ideological guards" mocked children of political

AA - interview with Rozália Halčinová (1955, Lendak) on April 20, 2015.

Ref. 2

Ref. 2

DOI: 10.1515/eas-2015-0012 C University of SS. Cyril and Methodius in Trnava. All rights reserved. 
prisoners. Anna Záborská, a daughter of political prisoner Anton Neuwirth, remembers: " $A$ teacher asked me in front of all many times: "Annie, where does your daddy work?" While perfectly knowing that he is being held in prison. This way she wanted to mock me." After such a show from the teacher, she replied: "Daddy works at prison in Leopoldov. And you know very well why."8

In other cases, the regime blackmailed parents through children. "They can kill me, but if my kid is not even allowed to kindergarten because he is a son of political prisoner, that ishorrible," said a political prisoner and writer Rudolf Dobiás. He himself got to prison as a student of Gymnázium in Trenčín. He was sentenced to eighteen years for a caricature of Stalin. "That caricature I did not even draw. I can't and couldn't draw a fish, surely not a person." "We may continue with examples of persecutions of students. It would be naive to think that such events did not affect their family. Mostly when mothers ended up in prison (some who died along the sentence), despite the enormous care of fathers, a family life of children went over the years the other way.

On the other hand, there were students who were ideologically influenced and who became a tool in the hands of teachers. Rudolf Dobiáš described in one of his short stories one such event: “...As he walked back, he decided he won't tell about his visit of Secret Police to anyone, not even to his father, from whom he secretly expected approval of his deed," says Dobiáš, reciting his own prosaic verses, in which he describes what happened a few days later. Rudolf Dobiás speaks about the events on the street of 29th August, how it was surrounded and how were one man, a woman and a girl dragged out of the house n.53 by the police. The boy and his mother were standing in the window and looking at what was happening "...She stood there with her hands over the mouth, as if she was fighting the cry or scream. "This was the Secret Police", whispered woman to her son, "Oh my God; they had found another Judas, who sold those poor people. "I sold them," said boy, after the longest pause in his life ever. Mother silently closed the window, covered her face in hands and walked out of a room. She felt as if her hearth had stopped. Momment later, the boy followed her. He found her ..."

Another sphere in which the school played its role was in how state holidays were celebrated, how the friendship of the USSR was highlighted, how the role of J.V. Stalin and the Revolution of 1917 were presented. Here we need to realize a role of a teacher in rural areas. Teacher belonged to the main representatives of a village. After 1948 there was an

8 AA - interview with Anna Záborská (1948, Zürich) and following email communication.

$9 \quad$ AA - interview with Rudolf Dobiáš (1934, Dobrotivá) and following email communication.

DOI: 10.1515/eas-2015-0012 C University of SS. Cyril and Methodius in Trnava. All rights reserved. 
effort to radically change the village life. The term "socialization of villages" hid in the reality a collectivization of property. A teacher (after 1948 the number of men in profession declined and rose the number of women teachers) became a voice for transmitting the decisions of the state to common people. Teachers thus became agitators. The archives in Spišská Sobota store student essays which present a clear intention to alter thinking of students. Teachers assigned homework to write an essay with the topic of Why my father did not join JRD (Union of Collective Farms). ${ }^{10}$ However, rather than being a writing exercise for the students, the essays were an instrument of the teacher communicating a message to the parents: "Parents, think about the fact that thanks to you joining the collective farming union we may earlier build progress of socialism." ${ }^{\text {"11 }}$ Essays from the village of Kravanylack any personal opinion of students toward the collectivization. Their essays are reminders of teachers about the collectivization towards parents. The students of eighth grade in Nižná Šuňava were allowed to express themselves more freely, therefore their works are more internally diverse. ${ }^{12}$ Two of these works finish with words: "I want my parents to join collective farms. I know work there is easier and better," although the children also pointed out other aspects of creation of collective farms. "In 1948 collectives were created in Nižná Šuñava. Only a few farmers joined them. Neither did my parents." They did not join because they had seen bad example of governance over the farms: "Farmers from Štrba dried grass on autumn and collected potatoes only when the snow was falling. Other farmers had crops and all the harvest stored at that time." Another reason was a relationship toward the expensive land that farmers had bought. Student Ján wrote: "My parents refuse to enter collectives because they had paid a sum of money toward the landowner and they had paid huge taxes for it. Now that Nižná Šuñava elected board of JRD, fertile land was taken from us and we were left with useless one, that nothing grows on. That's why my parents refuse collective farms." ${ }^{13}$

We discover the opinions of parents through their children, students of the schools. On the one hand, works include: "My father said that I should write to my essay "why he

10 State Archive Levoča, office in Poprad, fond Regional National Council Kežmarok (ONV KK), Department of education and culture, box 33,1960 , Why my parents did not join the collective farms.

11 Ref. 10

12 There are no other work within the region in the archives. We spoke with colleagues in USTR in Czech Republic, who could not retrieve such valuable archives. We would like to thank to workers of regional office of archives for such valuable artifacts.

13 State Archive Levoča, office in Poprad, fond Regional National Council Kežmarok (ONV KK), department of education and culture, box 33, 1960, Why my parents did not join the collective farms.

DOI: 10.1515/eas-2015-0012 C University of SS. Cyril and Methodius in Trnava. All rights reserved. 
refuses collectives" that he would not earn enough for the family." "If father works at collective farms, they won't earn enough on bread." "I asked my parents yesterday. They said, that when the house is build, we sign it. In short time we will be part of collective farming. "On the other hand there were common reactions such as: "He doesn't want to join collective farms. He refuses to tell me why." children the real reason because they were not sure if what they say won't be used against them. The works of students show also sentences like this: "My parents were yesterday in Poprad, where they were persuaded to join collectives' (...) If all the people inthe village had joined collective farms my parent would have joined too. " $"$ Essays which the children wrote the day after the event of persuasion prove that they were a part of premeditated and aimed plan on private farmers, and also that there was a cooperation between the teachers and propaganda. The important moment resonates: one day, an event full of persuasion of parents; second, teachers push pressure more through children that bring home essays.

Children of parents who actually joined the union wrote more freely about what was happening in collectives. Majority of students wrote about the positives of the union: collective farming, machines replacing hard work of people, use of fertilizers that results in higher harvest of produce and the fact that they do not need to work on their own farm. The essays also pointed to some negatives connected to the activities of the unions that they collected from their parents: larceny, lack of cattle, low turnovers, lower salary compared to builders. "Despite the benefits of collective farming, there may be negatives as well. The biggest one is that members are not united in opinions. Many times property of collectives is being stolen away." "Women who work with crops have no job for the winter. The fact is that when father was a builder he had earned much more than at collective farms. When we count it all together, he earns nothing more than before. As a farmer he did not get much better. He had to work from dawn till dusk and give a small part to the state by law." "There is more to negative side of collective farms than positive. Some are due to nepotism. Another vice that haunts collectives is that managers avoid their responsibilities. That demotivates people, they do not trust them and therefore they lose any motivation for work. Also, they were promised to be paid 17 CZK but capacities were not fulfilled. People were paid 10 CZK per unit a month. The rest was supposed tobe paid later but plans went awry. People lack money." This situation is getting worse by the fact that people were not paid for December and end-of-year report from last year has not been done yet. Although, these shortcomings we are trying to fix, for example through the election of new board. New 
board has been trying enormously to fix the situation but without help of people it won't work. We lack cooperation of the board and people, because they lost motivation to work. Now what remains is to persuade people to come back to work with motivation and enthusiasm to build socialism. ${ }^{16}$ Children of members recounted positives and negatives. Their works reflect the result of propaganda: with enthusiasm change the society through collective farming unions.

Not only primary schools students but also high school students whose parents refused to join collectives were under pressure. There are known cases of young boys who were not allowed to basic army service but to supporting forces; students, who were not allowed to study at better high schools and later on at universities. Through exclusion from schools and university ... attitude toward the regime formed as well within those who were accepted and allowed to study.

The Department of Education and Culture in Kežmarok asked their colleagues from Sečovce (September 16, 1957), to send someone to Malý Slavkov to persuade teacher Majerčáková about collective farming: "because her parents refuse to enter collectives, and so she can help us to overcome these problems, that are connected with this offer.. ${ }^{17} \mathrm{We}$ can see in this example how even later in 1957 prominent people within the regime were occupied by thought of manipulation toward the collectivization. "Parents of named person are negative toward the socialization in rural areas and therefore it is important to use this way persuasion." 18

\section{How teacher forms their students in present}

The present is not separated from the past. It influences us, it influences students through outside environment, but also through content of the curriculum provided by teachers. Nevertheless, nostalgia of ones who rememberthe times of communist regime talks about young period of their lives rather than about knowing the truth about their times. Nostalgia without knowing the truth and complete understanding reality can (and especially in the eyes of older generation who lived through those times) celebrate the role of Adolf Hitler who opened the way for Germany towards the economic prosperity, how he built highways,

State Archive Levoča, office in Poprad, fond Regional National Council Kežmarok (ONV KK), department of education and culture, box 33, 1960, Why my parents did not join the collective farms.

17 State Archive Levoča, office in Poprad, fond Regional National Council Kežmarok (ONV KK), Socialization of village. $8861 / 2 \mathrm{SpS}$.

Ref. 17

DOI: 10.1515/eas-2015-0012

(c) University of SS. Cyril and Methodius in Trnava. All rights reserved. 
lowered unemployment. We can celebrate Stalin for his efforts to build strong empire out of the USSR. Although, can we forget millions of victims, hunger of Ukraine and violent collectivization? It seems like that in Slovakia we can. A few years ago I was reminded this by a statue of Stalin in front of Slovak National Gallery (SNG). Even though the creators used it as a marketing tool to attract ("Stalin is not in the center of square, he is not at pedestal"), the reality was different. People from trams that stopped nearby were forced to see his smiling face. Seeing smiling Stalin I was reminded of monstrosities from Jáchymov, where prisoners were forced to look at bodies of their comrades that were shot to dead as they tried to escape. It was a paradox of the past and present. The symbol of tyranny has become a smiling old man at the square in Slovak capital city. Where are the victims? Many tourists took photos the same way they take bench with Napoleon or "the man at work"19: "I don't want to take a photo next to the man who is responsible for the loss of 20 million lives," I was told by a visitor from Argentina, whose mother escaped from Czechoslovakia in 1950. Mrs. Šestáková expressed her opinion in similar way: "I feel offended!"

It is against all morality that even SNG informed by short text that new statues of Stalin are being raised in Russia. If public sector rehabilitates Stalin and provides untruthful information within the state institution, what about teacher and school? Is it not schizophrenic, dual, unclear once more?

The environment in schools is even worse. History of the 20th century is being used in curriculum only partially. But understanding of the past is more than important. If a student has a clear understanding about the past, he is not inclined toward the radicalism. Adrian von Auburg says: "If we resign on systematic understanding of History, we leave dealing with the past - this ancient human need, that every person will forever want to satisfy, any civilization too- way too lightly to Media, for which it is randomness and arbitrariness; to politicians, who are not ashamed to use methods of populism and also to disorganized spread of myths and lies.The result then is the total degradation of every peace from the past, and from there it is a small step toward the relativization of present. Nobody will know what the truth is or what is fiction within the piece of news " 20 The past directly connects with understanding of the present, and therefore it is necessary to understand it for the sake of the past and future. We can see the stories of suffering and

19 There are few statues in the centre of Bratislava which point to some historical events, figures of Bratislava, or are just funny.

20 ARBURG, Adrian: Decade of catastrophies in 1938 - 1948 in the view of historical research. In. Tragic places of memory. Tragischeerinnerungsorte. Prague: Antikomplex, 2010. p. 35.

DOI: 10.1515/eas-2015-0012 C University of SS. Cyril and Methodius in Trnava. All rights reserved. 
unlawfulness through the stories of political prisoners. ${ }^{21}$ On the other hand we also come to people who had anchored values, who did not cease to pragmatism and totalitarian regimes. They are inspiration for those who struggle for life full of ideals. "Every person who suffered this much caries around a sentence about the regime itself that spread this suffering. "22

The dialogue between a teacher and a student many time offers a feedback on how important is to know the past. On the other hand, internet full of information somehow shifts priorities away from facts. Teachers talk about the need to teach about values. Some, even methodologists of History, consider feelings and understanding through historical empathy as the most important part of education. ${ }^{23}$ But is education to values the same method which was used for personal formation of students during the communist regime? It is not. Teacher today does not want to present colorless world, bounded by boarders and knowledge. Teachers prefer to raise an honorable citizen instead.

When we worked with a few teachers on some educational materials about Chart 77, all five of them preferred values to knowledge potential of the document; a spirit of participation instead of indifference and pragmatism. According to them, this way they can better help students to understand through this document that particular situation, what Chart 77 meant for society, more than just some knowing facts about it.

After the mock lesson they said, that the content of the lesson helped students especially in empathy (historical empathy) and the least in factual knowledge. They arrange it as following:

21 The Communism regime lasted in Czechoslovakia since 1948 until November 1989. More than 705 people had lost their lives due to political decisions. More than 16000 people were violently moved and 13000 was placed to working camps. 22000 citizens left the country without permission for what they were sentenced in absence. To more than 53000 years were sentenced 71000 people. Global experience with the Communism is even terrible. Authors of Black book of Communism speak about 100 milion of dead.

MIKLOŠKO, František: View on Communist period and first years of freedom. In. Overcoming the abuse of power in Church and Society.Trnava: Dobrá kniha, 2012. p. 11.

22 NEUPAUER, František: Aj Rumuni majú „múzeum komunizmu“ [Also Romanians have Museum of Communism]. www.postoy.sk, September 13, 2012.

23 Historical empathy is what means to understand why somebody knows what other feels, why he did what he did. Historical empathy deals with historical analysis and behaviour of people with respect to dedailed empathy to human behaviour. Compare also STEWAED, E. (2011). 9/11 is a story of people. Retrieved August 6, 2011. Available on:

www.nydailynews.com/opinions/2008/09/11/2008-09-11_911_is_a_story_of_people.html

DOI: 10.1515/eas-2015-0012 C University of SS. Cyril and Methodius in Trnava. All rights reserved. 
EMPATHY (Historical empathy) - they were able to feel and understand people who had lived in such a period of time,

EMOTIONS (2a) and VALUES (2b) - on the one hand students read actions of people, but also they understood what does it mean to spread values and live by them,

FACTS - this meant for them mainly how well students remembered facts and information. This was according to them not the aim of the lesson, and it would be mistake due to such an importance of Chart 77 to follow pure historical facts on this lesson.

On the contrary, discussions prove that the facts and memorizing still play bigger part of education today. Students need facts to participate at competitions. Somehow understanding of the period when it comes to essays still remains in the back. When we force students to think, they are afraid and ask: "What do you want from us?" It is interesting to find out that teachers do not consider the lessons of history not based on facts negatively, rather the opposite. They valued that their students were touched by emotions. (e.g. "Why you didn't answer the questions ?" Student: "I was surprised.") Spreading of the values, linked to the present, is also valued as positive.

\section{Conclusion}

During the communist regime in Czechoslovakia after 1948,the teacher became prolonged arm of communist party and ideology. A teacher who disagreed with the regime but wanted to be the part of the education, was often under pressure of autocensorship. A student, who was exposed to duality in family and school, listened to "Western stations" and followed the rules, was becoming a victim of schizophrenia (to speak differently at home and school). Especially when it came to changes in rural areas, the regime had a strong position in its attempts of forming young generation for own purpose.

Nowadays, it seems like the state has no intention to hide information. But public space, or lowering the number of history lessons at schools raises unease; it may seem like schools do not allow enough space for information to students, and by this it forces them indirectly to radicalization (it is easier to believe to propaganda and lies). Contemporary teachers consider important to raise the emotions within students, teach them to values. Surely, this can be important, but it can be dangerous as well. The fact that we have some values defined as today does not mean that we will hold the same definitions 10 years later. What if value based education will bring another ideology? These questions will require search for answers, even if nowadays they may seem irrelevant. 


\section{Bibliography}

ARBURG, Adrian: Decade of catastrophies in $1938-1948$ in the view of historical research. In. Tragic places of memory. Tragischeerinnerungsorte. Prague: Antikomplex 2010.

MIKLOŠKO, František: View on Communist period and first years of freedom. In. Overcoming the abuse of power in Church and Society.Trnava: Dobrá kniha, 2012.

NEUPAUER, František: Aj Rumuni majú „múzeum komunizmu“ [Also Romanians have Museum of Communism]. www.postoy.sk, September 13, 2012.

STEWAED, E. (2011). 9/11 is a story of people. Retrieved August 6, 2011. Available on: www.nydailynews.com/opinions/2008/09/11/2008-09-11_911_is_a_story_of_ people .html

WINCZER, P.: Gymnázium v Kežmarku, High school of Kežmarok in $1950-1953$ viewed from personal retrospective. In. Goceliaková, M. (comp.): 75 years of High school in Kežmarok: Alter ego 2003.

\section{Archival materials}

Author's archive (AA) - interview with Peter Dubovský (1921, Rakovice - 2008, Ivánka pri Dunaji), interview with Rozália Halčinová (1955, Lendak), interview with Anna Záborska (1948, Zürich), interview with Rudolf Dobiáš (1934, Dobrotivá)

State Archive Levoča, office in Poprad, fond Regional National Council Kežmarok (ONV KK) 